\title{
PENERAPAN SMART SENSOR UNTUK KENDALI PH DAN LEVEL LARUTAN NUTRISI PADA SISTEM HIDROPONIK TANAMAN PAKCOY
}

\author{
Fitri Rahmah ${ }^{1}$, Fitria Hidayanti ${ }^{2}$, Mutma Innah $^{3}$ \\ 1,2,3 Fakultas Tenik dan Sains, Universitas Nasional Jakarta \\ Email: ${ }^{1}$ fitri.rahmah@civitas.unas.ac.id, ${ }^{2}$ fitriahidayanti@gmail.com, ${ }^{3}$ mutma.innah215@gmail.com
}

(Naskah masuk: 31 Januari 2019, diterima untuk diterbitkan: 02 Oktober 2019)

\begin{abstract}
Abstrak
Penerapan smart sensor untuk kendali parameter $\mathrm{pH}$ dan level larutan nutrisi pada tanaman hidroponik bertujuan untuk memenuhi nutrisi tanaman secara otomatis dan kontinu. Sistem kendali closed loop dirancang untuk mengkondisikan parameter $\mathrm{pH}$ pada rentang nilai 6-7, serta parameter level larutan nutrisi pada rentang nilai 18$20 \mathrm{~cm}$. Ketika nilai $\mathrm{pH}$ berada di bawah 6 , maka aktuator solenoid valve di larutan basa akan terbuka secara otomatis dan mengalir ke larutan nutrisi. Begitu juga ketika nilai $\mathrm{pH}$ berada di atas 7 maka solenoid valve larutan asam yang akan terbuka secara otomatis. Solenoid valve menutup kembali ketika sensor mendeteksi nilai $\mathrm{pH}$ pada rentang 6-7. Selanjutnya, sensor level ultrasonik digunakan untuk mendeteksi ketinggian level larutan nutrisi. Ketika sensor level mendeteksi ketinggian larutan nutrisi pada nilai $18 \mathrm{~cm}$, maka aktuator solenoid valve pada tangki nutrisi cadangan akan membuka untuk mengisi larutan ke tangki nutrisi utama. Solenoid valve akan menutup kembali ketika sensor mendeteksi ketinggian level di tangki nutrisi utama senilai $20 \mathrm{~cm}$. Berdasarkan data pemantauan $\mathrm{pH}$ dan level larutan nutrisi selama masa tanam, larutan nutrisi yang tersirkulasi pada media hidroponik sesuai dengan kebutuhan tanaman pakcoy. Sistem smart sensor untuk pengendalian bekerja sesuai dengan set point parameter $\mathrm{pH}$ dan level larutan nutrisi yang ditetapkan. Tanaman pakcoy terpantau tumbuh secara signifikan berdasarkan penambahan jumlah dan panjang helai daun sepanjang 25 hari masa tanam di media hidroponik.
\end{abstract}

Kata kunci: hidroponik, kendali, level nutrisi, pH, smart sensor

\section{SMART SENSOR APPLICATION FOR PH AND NUTRITION LEVEL CONTROL IN HYDROPONIC SYSTEM OF PAKCOY PLANT}

\begin{abstract}
The application of smart sensors to control $\mathrm{pH}$ and nutrient level parameters in hydroponics plants aims to supply the nutrients of plants automatically and continuously. The working principle of a closed loop control system is designed to stabilize the pH parameters in the 6-7 values range, as well as the nutrient level parameters in the 18$20 \mathrm{~cm}$ height range. While the measured $\mathrm{pH}$ value is below 6 , the solenoid valve as an actuator of the base solution will open automatically and flow into the nutrient solutions. Likewise, when the measured pH value is above 7, the solenoid valve in acid solution will open automatically. The solenoid valve will close when the measured pH values are in the range of 6 to 7. Furthermore, the ultrasonic level sensor is used to measure the height of the nutrient level. When the level sensor measure the height of the nutrient level at a value of $18 \mathrm{~cm}$, the solenoid valve as an actuator in the reserve nutrient tank will open automatically to fill in the main nutrient tank. The solenoid valve will close when the measured level value in the main nutrient tank is $20 \mathrm{~cm}$. Based on the data monitoring of pH and nutrient levels during the planting season, the circulation of nutrient solutions is appropriate for the pakcoy plants. The control system based smart sensor shows works according to the set point of the pH and nutrient level. The pakcoy plants were monitored to grow significantly based on the number and length of the leaves during the 25 days of planting in hydroponic media.
\end{abstract}

Keywords: hydroponics, control, nutrient level, $p H$, smart sensor

\section{PENDAHULUAN}

Tanaman pakcoy (Brassica rapa L.) merupakan salah satu jenis sayuran yang digemari oleh masyarakat Indonesia. Di Indonesia banyak terdapat jenis makanan yang menggunakan daun pakcoy sebagai bahan makanan utama maupun sebagai pelengkap (Vivonda and Yoseva, 2016). Pakcoy selain sebagai sayuran juga bermanfaat bagi 
kesehatan manusia. Hal ini karena pakcoy masuk pada kategori sayuran cruciferous yang banyak mengandung senyawa glukosinolat. Glukosinolat memiliki kemampuan antibakteri, salah satunya terhadap escherchia coli, yaitu bakteri penyebab diare (Wahyuni, 2014).

Glukosinolat juga merupakan bahan dasar isothiocyanate, yaitu senyawa yang mampu berfungsi sebagai antikanker (Kim and Park, 2009, Herr and Büchler, 2010, Kestwal et al., 2011), merangsang enzim untuk detoksifikasi (Boivin et al., 2009), dan menstimulasi sistem kekebalan tubuh (Francisco et al., 2009).

Beragam manfaat pakcoy bagi kesehatan menjadikannya sebagai salah satu tanaman daun yang memiliki nilai ekonomis tinggi. Pakcoy memiliki prospek dikembangkan karena permintaan pasar dan harga yang tinggi dibandingkan dengan jenis sawi lainnya. Namun, ketersediaan lahan subur untuk bercocok tanam khususnya di area kota besar semakin terbatas (BPS, 2015). Maka, teknik hidroponik dapat menjadi salah satu solusi untuk budidaya pakcoy pada lahan yang terbatas (Hussain et al., 2014, Saha, 2010).

Hidroponik merupakan teknik budidaya tanaman tanpa media tanah. Hidroponik lebih efisien daripada bercocok tanam pada media tanah karena penggunaan air yang lebih sedikit (Savvas, 2003). Perawatan tanaman lebih mudah karena media tanam relatif bersih, serta nutrisi dan akar tanaman mudah dipantau. Hidroponik mampu mendukung panen secara terus-menerus sepanjang tahun (Barbosa et al., 2015).

Hidroponik dapat dijadikan sebagai sistem pertanian masa depan ketika populasi penduduk meningkat, kebutuhan pangan bertambah, dan kondisi lahan tidak termanajemen dengan baik (Sheikh, 2006, Sardare and Admane, 2013). Hidroponik menghasilkan sistem pertanian yang baik dan efisien, karena panen melimpah dengan energi seminimal mungkin untuk produksi secara terus menerus sepanjang tahun (Rasul, 2016).

Tanaman hidroponik ditanam pada media berporos yang selanjutnya dialiri dengan air kaya nutrisi. Nutrisi yang terkandung pada hidroponik diperoleh melalui beberapa jenis garam yang mudah larut di dalam air. Garam tersebut mengandung unsur fosfor $(\mathrm{P})$, nitrogen $(\mathrm{N})$, kalium $(\mathrm{K})$, kalsium $(\mathrm{Ca})$, magnesium $(\mathrm{Mg})$, sulfur $(\mathrm{S})$, mangan $(\mathrm{Mn})$, besi $(\mathrm{Fe})$, seng ( $\mathrm{Zn}$ ), boron (B), molybdenum (Mo), dan tembaga $(\mathrm{Cu})$. Larutan nutrisi merupakan pengganti unsur hara pada tanah dan menjadi nutrisi bagi tanaman (Nguyen et al., 2016, Sheikh, 2006, Sardare and Admane, 2013, Rosliani and Sumarni, 2005). Saat ini larutan nutrisi untuk hidroponik bisa menggunakan larutan $\mathrm{AB}$ mix. Larutan nutrisi $\mathrm{AB}$ mix telah mencakup unsur garam yang telah disebutkan sebelumnya (Resh, 2016). Ketinggian larutan nutrisi perlu untuk dipantau dan dikendalikan agar proses suplai ke tanaman tidak terganggu.
Sensor ultrasonik merupakan salah satu perangkat yang dapat mengukur ketinggian larutan nutrisi. Sensor mengukur jarak objek dengan mengirimkan gelombang suara dan menerima hasil pantul gelombangnya untuk dapat menghitung jarak antara sensor dan objek (Carullo and Parvis, 2001). Pada penelitian ini, sensor ultrasonik yang digunakan adalah sensor ultrasonik HC-SR04.

Selain ketinggian larutan nutrisi, parameter derajat keasaman atau $\mathrm{pH}$ pada tanaman pakcoy juga harus terpenuhi. Parameter $\mathrm{pH}$ berperan pada penyerapan larutan nutrisi oleh akar tanaman. Nilai pH pada tanaman pakcoy berada pada rentang 6-7 (Istarofah and Salamah, 2017).

Parameter $\mathrm{pH}$ pada hidroponik penting karena berfungsi sebagai penghantar nutrisi ke akar tanaman. Nilai $\mathrm{pH}$ setiap tanaman berbeda-beda. Hal ini dikarenakan kemampuan akar tanaman yang berbeda pula dalam menyerap ion-ion dalam larutan nutrisi. Nilai $\mathrm{pH}$ dapat ditingkatkan dengan menambahkan larutan basa seperti kalium hidroksida, serta nilai dapat diturunkan dengan menambahkan larutan asam seperti asam fosfat (Nugraha, 2014).

Pengukuran dan pengendalian nilai $\mathrm{pH}$ menggunakan sensor $\mathrm{pH}$. Sensor $\mathrm{pH}$ masuk ke dalam kelompok sensor kimia, karena mampu mengubah besaran kimia menjadi besaran listrik. Komponen sensor terdiri atas elektroda pengukuran, elektroda referensi, serta transmiter. Elektroda pengukuran sensitif terhadap ion hydrogen dan menjadi kutub positif. Sedangkan elektroda referensi menjadi kutub negative. Beda tegangan antar kedua kutub akan menghasilkan nilai $\mathrm{pH}$ sebuah larutan (Glasoe and Long, 1960).

Apabila nilai $\mathrm{pH}$ tidak sesuai dengan yang dibutuhkan, maka penyerapan larutan nutrisi tidak maksimal sehingga mempengaruhi pertumbuhan tanaman pakcoy. Oleh karena itu, dibutuhkan suatu sistem kendali otomatis agar larutan nutrisi tanaman pakcoy tetap terjaga sesuai dengan nilai $\mathrm{pH}$ yang dibutuhkan.

\section{METODE PENELITIAN}

Penelitian dilaksanakan sesuai dengan urutan pada diagram alir Gambar 1. Pada desain dan pemilihan komponen, alat dan bahan yang digunakan antara lain Arduino Uno sebagai pengendali, sensor Ultrasonik HC-SR04 sebagai sensor level larutan nutrisi, sensor $\mathrm{pH}$, LCD untuk menampilkan hasil pembacaan sensor, solenoid valve sebagai aktuator, pompa untuk mengalirkan larutan nutrisi, simcard module untuk Arduino sebagai alat perekaman data pengukuran secara real time, kemudian real time clock Arduino untuk mengatur waktu pengambilan data. Selanjutnya pipa, sambungan pipa, larutan nutrisi $\mathrm{AB}$ mix, larutan $\mathrm{pH}$ asam dan basa, tangki nutrisi, net pot, dan selang merupakan komponen yang dibutuhkan untuk sistem hidroponik. 


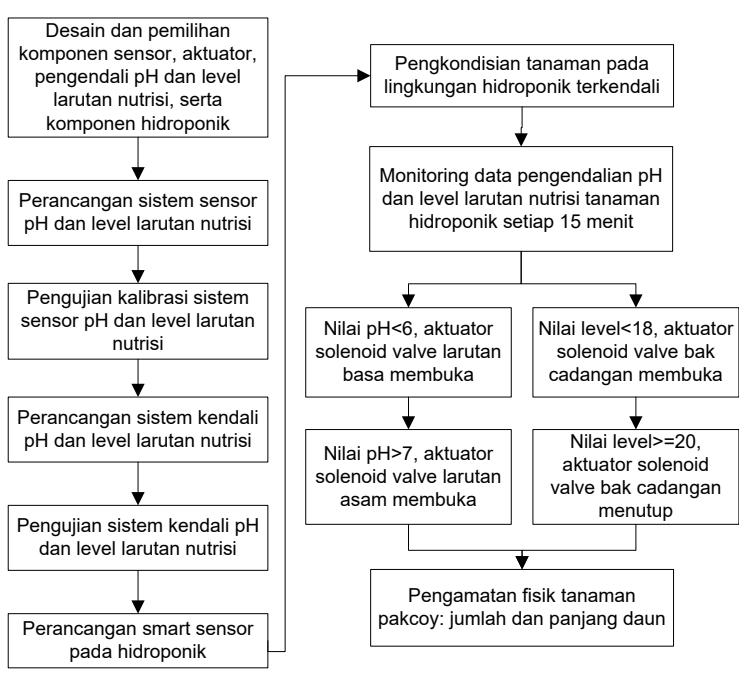

Gambar 1. Diagram alir penerapan smart sensor untuk kendali $\mathrm{pH}$ dan level larutan nutrisi

Pada tahap perancangan sistem sensor $\mathrm{pH}$, dilakukan integrasi komponen sensor $\mathrm{pH}$, Arduino Uno, dan LCD. Hal yang sama juga dilakukan pada sistem sensor level larutan nutrisi. Selanjutnya pengujian kalibrasi dilakukan sesuai pemaparan pada bagian 2.1. Kemudian pada tahap perancangan sistem kendali, dilakukan integrasi komponen pengendalian sesuai dengan skema Gambar 4. Pengujian sistem kendali dilakukan berdasarkan penjelasan pada bagian 2.2.

Sistem hidroponik kemudian dirakit dan diintegrasikan dengan sistem kendali berbasis smart sensor sesuai skema Gambar 5 pada bagian 2.3. Tanaman pakcoy yang telah disemai selanjutnya dipindahkan ke hidroponik yang telah terintegrasi dengan smart sensor. Sistem secara kontinu melakukan pemantauan dan pengendalian $\mathrm{pH}$ dan level larutan nutrisi sesuai dengan set point yang telah ditentukan. Laju pertumbuhan tanaman ditinjau melalui jumlah dan panjang daun selama 25 hari masa tanam di sistem hidroponik.

\subsection{Pengujian Kalibrasi Sistem Sensor}

Proses kalibrasi nilai $\mathrm{pH}$ dilakukan agar nilai $\mathrm{pH}$ yang dihasilkan oleh alat sesuai dengan nilai $\mathrm{pH}$ yang sebenarnya. Sensor $\mathrm{pH}$ dikalibrasi dengan larutan buffer dengan $\mathrm{pH}$ 4.01, 7,01 dan 10,01. Gambar 2 menunjukkan skema kalibrasi sensor $\mathrm{pH}$.

Sensor level larutan nutrisi menggunakan pengukuran besaran panjang. Untuk itu, sensor tersebut dikalibrasi dengan standard satuan panjang. Standard ukur yang digunakan adalah gauge block yang memiliki nilai panjang tertentu. Pengujian dilakukan dengan variasi jarak $10 \mathrm{~cm}, 20 \mathrm{~cm}, 30 \mathrm{~cm}$, $40 \mathrm{~cm}$, dan $50 \mathrm{~cm}$. Proses kalibrasi sistem sensor level ditunjukkan pada Gambar 3.

\subsection{Pengujian Sistem Kendali}

Terdapat dua variabel yang dikendalikan yaitu $\mathrm{pH}$ dan level larutan nutrisi. Pengujian dilakukan sebelum tanaman diaplikasikan pada media hidroponik. Gambar 4 menunjukkan blok diagram sistem kendali closed loop. Nilai set point pengendalian $\mathrm{pH}$ ditetapkan sebesar 6-7. Aktuator berupa solenoid valve masing-masing dipasang pada larutan asam dan basa. Ketika nilai $\mathrm{pH}$ berada di bawah 6, maka solenoid valve larutan basa akan secara otomatis membuka sampai nilai $\mathrm{pH}$ terbaca 6 . Sebaliknya, ketika nilai $\mathrm{pH}$ berada di atas 7 maka solenoid valve larutan asam yang akan secara otomatis membuka sampai nilai $\mathrm{pH}$ terbaca 7.

Pada pengendalian level larutan nutrisi, nilai set point yang diinginkan adalah $18 \mathrm{~cm}$ hingga $20 \mathrm{~cm}$. Aktuator solenoid valve dipasang pada tangki nutrisi cadangan. Ketika nilai level larutan nutrisi pada tangki nutrisi utama terbaca kurang dari $18 \mathrm{~cm}$, maka solenoid valve pada tangki nutrisi cadangan akan membuka, dan menutup saat level larutan berada pada ketinggian $20 \mathrm{~cm}$.

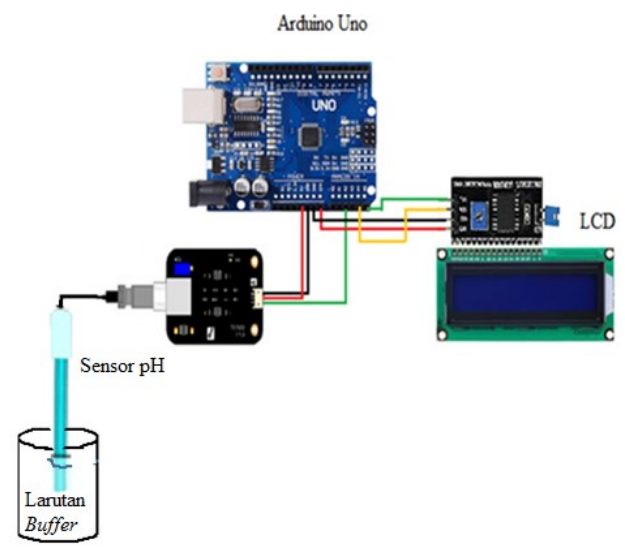

Gambar 2. Skema kalibrasi sensor $\mathrm{pH}$

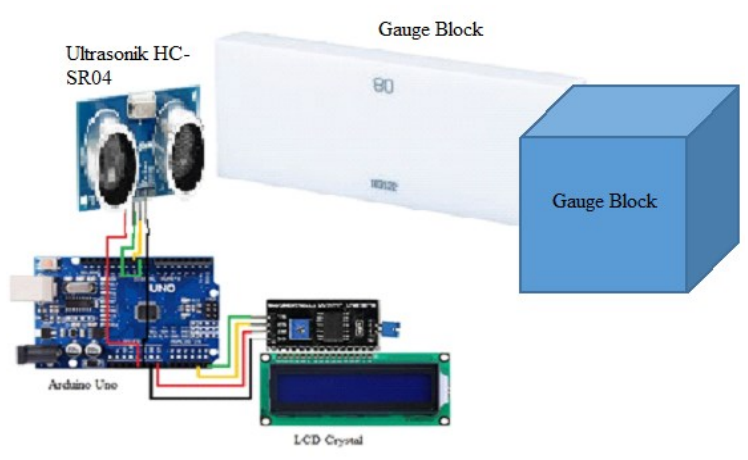

Gambar 3. Skema kalibrasi sensor level larutan nutrisi

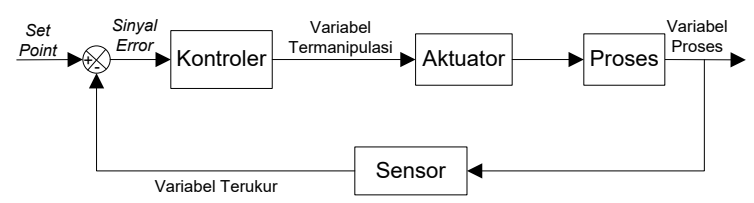

Gambar 4. Diagram blok sistem pengendalian 
Pengujian sistem kendali pH dilakukan dengan menetapkan $\mathrm{pH}$ larutan nutrisi mula-mula pada kondisi asam dan kondisi basa. Kemudian dilakukan analisis terhadap respon waktu sistem pengendalian $\mathrm{pH}$ tersebut. Sedangkan pengujian sistem kendali level dilakukan dengan menetapkan ketinggian mulamula pada kondisi kurang dari $18 \mathrm{~cm}$. Selanjutnya dilakukan analisis terhadap respon waktu sistem pengendaliannya.

\subsection{Perancangan Smart Sensor pada Hidroponik}

Sistem smart sensor yang dirancang mengintegrasikan antara pengendalian parameter $\mathrm{pH}$ dan level larutan nutrisi dengan hidroponik tanaman pakcoy. Perancangan sistem kendali berbasis smart sensor ditampilkan pada Gambar 5.

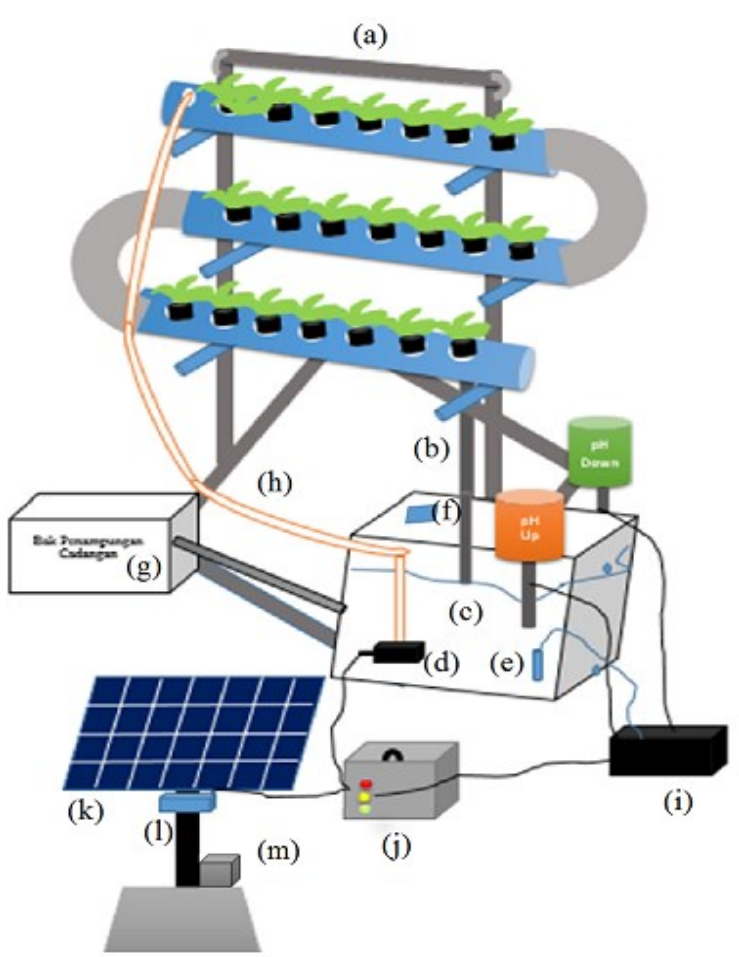

Gambar 5. Skema smart sensor pada kendali parameter $\mathrm{pH}$ dan level larutan nutrisi

Keterangan:

(a) : kerangka hidroponik

(b) : selang aliran air ke tangki nutrisi utama

(c) : tangki nutrisi utama

(d) : pompa air dc

(e) : sensor $\mathrm{pH}$

(f) : sensor level ultrasonik

(g) : tangki nutrisi cadangan

(h) : selang aliran tangki nutrisi utama ke tanaman

(i) : box controller

(j) : power supply

(k) : panel surya

(l) : aki

(m): solar charger controller

\section{HASIL DAN PEMBAHASAN}

Smart sensor untuk sistem kendali parameter $\mathrm{pH}$ dan level larutan nutrisi tanaman hidroponik diuji dengan beberapa kondisi.

\subsection{Analisis terhadap Pengujian Kalibrasi Sensor}

Pengujian kalibrasi pada bagian 2.1 dilakukan sebanyak 3 kali pengulangan untuk masing-masing titik ukur. Tabel 1 dan Tabel 2 menunjukkan hasil pengujian kalibrasi untuk masing-masing sensor. Hasil perhitungan nilai kesalahan pembacaan sensor masih berada pada batas toleransi, sehingga sensor dapat digunakan sebagai alat untuk mengukur besaran fisis.

\begin{tabular}{cccccc}
\multicolumn{5}{c}{ Tabel 1. Hasil Pengujian Kalibrasi Sensor pH } \\
\hline $\begin{array}{c}\text { pH } \\
\text { larutan } \\
\text { buffer }\end{array}$ & $\begin{array}{c}\text { pH sensor yang diuji pada } \\
\text { pengujian }\end{array}$ & $\begin{array}{c}\text { rata- } \\
\text { rata }\end{array}$ & $\begin{array}{c}\text { \% } \\
\text { error }\end{array}$ \\
\cline { 2 - 5 } ke-1 & ke-2 & ke-3 & & 3,98 & 0,75 \\
4,01 & 3,98 & 3,97 & 3,99 & 3,99 \\
7,01 & 7,00 & 7,01 & 6,98 & 6,99 & 0,28 \\
10,01 & 9,96 & 9,98 & 9,98 & 9,97 & 0,40 \\
\hline
\end{tabular}

Tabel 1 menunjukkan bahwa nilai koreksi tertinggi pada titik ukur 10,01sebesar 0,04 dan terendah pada titik ukur 7,01 sebesar 0,02 . Adapun nilai error tertinggi pada titik ukur 4,01 yaitu $0,75 \%$ dan terendah pada titik ukur 7,01 yaitu $0,28 \%$. Dengan demikian, dapat disimpulkan bahwa error sensor $\mathrm{pH}$ yang digunakan dalam penelitian ini tidak melebihi toleransi.

Tabel 2. Hasil Pengujian Kalibrasi SensorLevel Ultrasonik

\begin{tabular}{|c|c|c|c|c|c|}
\hline \multirow{2}{*}{$\begin{array}{c}\text { Panjang } \\
\text { gauge } \\
\text { block } \\
\text { (cm) }\end{array}$} & \multicolumn{3}{|c|}{$\begin{array}{c}\text { panjang pembacaan sensor } \\
(\mathrm{cm})\end{array}$} & \multirow{2}{*}{ rata-rata } & \multirow{2}{*}{$\begin{array}{l}\% \\
\text { error }\end{array}$} \\
\hline & ke-1 & ke-2 & ke-3 & & \\
\hline 10 & 10,0021 & & 100018 & & 0,007 \\
\hline 20 & & & & & 0,050 \\
\hline & & & & & \\
\hline 40 & & & & 40,0020 & 0,100 \\
\hline 50 & 50,0019 & 50,0027 & 50,0023 & 50,0025 & 0,005 \\
\hline
\end{tabular}

Tabel 2 menunjukkan bahwa nilai koreksi tertinggi pada titik ukur $30 \mathrm{~cm}$ sebesar $0,0300 \mathrm{~cm}$ dan terendah pada titik ukur $10 \mathrm{~cm}$ sebesar $0,0007 \mathrm{~cm}$. Adapun nilai error tertinggi pada titik ukur $40 \mathrm{~cm}$ yaitu $0,1 \%$ dan terendah pada titik ukur $50 \mathrm{~cm}$ yaitu $0,005 \%$. Dengan demikian, dapat disimpulkan bahwa error sensor level ultrasonik yang digunakan dalam penelitian ini tidak melebihi toleransi.

\subsection{Analisis terhadap Pengujian Sistem Kendali}

Analisis berikutnya adalah terhadap hasil pengujian pada bagian 2.2. Pengujian dilakukan untuk mengetahui respon waktu sistem kendali ketika sensor mendeteksi adanya parameter nilai yang tidak sesuai dengan set point.

Gambar 6 menunjukkan respon waktu sistem pada saat nilai awal $\mathrm{pH}$ berada pada kondisi asam, yaitu 5,6. Kondisi ini menyebabkan solenoid valve pada larutan basa membuka dan mengalir ke larutan 
nutrisi. Solenoid valve selanjutnya menutup kembali ketika sensor mendeteksi nilai $\mathrm{pH}$ pada rentang nilai 6-7. Waktu yang dibutuhkan untuk mencapai nilai $\mathrm{pH}$ yang diinginkan pada pengujian ini yaitu 9 menit.

Gambar 7 menunjukkan hasil respon waktu sistem kendali pada saat nilai $\mathrm{pH}$ mula-mula berada pada kondisi basa, yaitu 7,5. Kondisi ini menyebabkan solenoid valve pada larutan asam terbuka dan mengalir menuju ke larutan nutrisi. Waktu yang dibutuhkan untuk mencapai nilai $\mathrm{pH} 7$ pada pengujian ini yaitu 11 menit.

Selanjutnya, pada pengujian sistem kendali level larutan nutrisi dilakukan untuk mengamati respon waktu yang dibutuhkan oleh solenoid valve pada tangki cadangan untuk membuka dan mengisi tangki nutrisi utama agar sesuai dengan set point yang telah ditentukan. Gambar 8 menunjukkan respon waktu sistem pengujian level larutan pada ketinggian awal $15,0 \mathrm{~cm}$. Hal ini menyebabkan solenoid valve pada tangki penampungan cadangan akan membuka dan mengalirkan larutan ke tangki nutrisi utama.

Sensor level akan secara real time mendeteksi bertambahnya ketinggian larutan di tangki nutrisi utama, Pada ketinggian $20,0 \mathrm{~cm}$ maka solenoid valve pada tangki cadangan akan menutup secara otomatis. Hasil pengujian Gambar 8 menunjukkan respon waktu sistem kendali agar level larutan nutrisi mencapai $20,0 \mathrm{~cm}$ yaitu selama 145 detik.

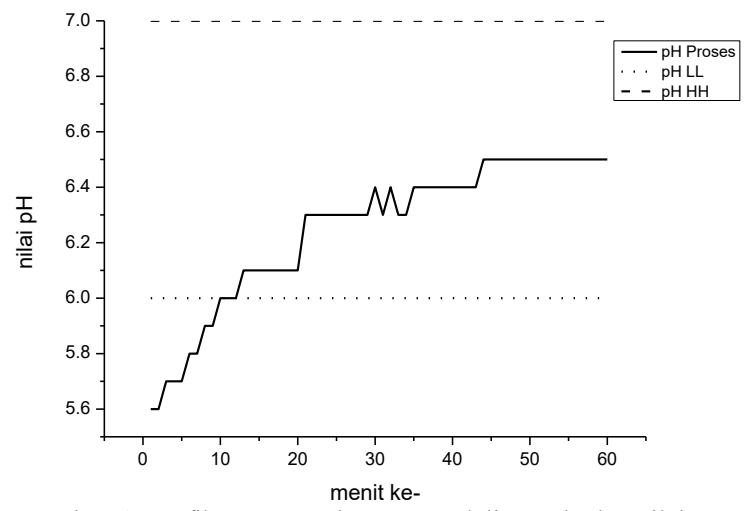

Gambar 6. Grafik respon waktu pengendalian terhadap nilai $\mathrm{pH}$ asam

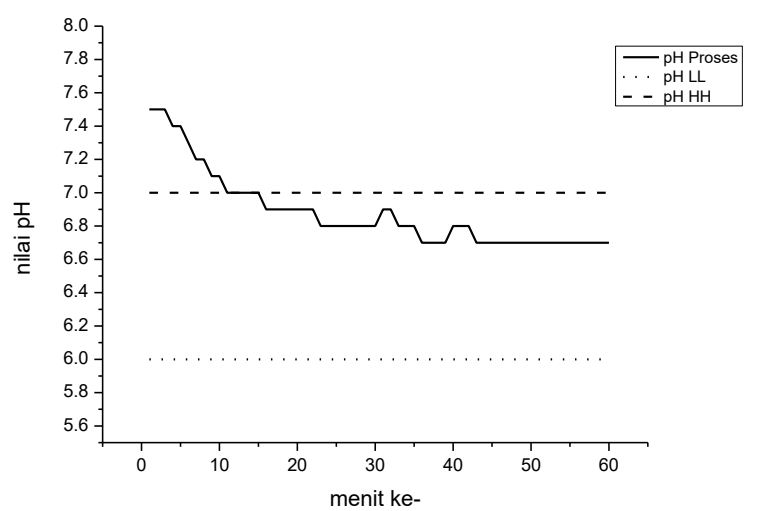

Gambar 7. Grafik respon waktu pengendalian terhadap nilai $\mathrm{pH}$ basa

Gambar 9 menunjukkan respon waktu pengujian level larutan pada ketinggian awal 18,0 $\mathrm{cm}$. Solenoid valve pada penampungan cadangan akan membuka dan mengalir ke tangki nutrisi utama. Waktu yang dibutuhkan untuk mencapai ketinggian level larutan $20 \mathrm{~cm}$ adalah 65 detik.

\subsection{Analisis terhadap Perancangan Smart Sensor pada Hidroponik}

Tanaman pakcoy yang telah disemai selanjutnya ditanam pada sistem hidroponik yang terintegrasi dengan smart sensor untuk pengendalian parameter $\mathrm{pH}$ dan level larutan nutrisi sesuai dengan skema pada bagian 2.3. Pada saat pengaplikasian, data nilai parameter tersebut tersimpan di dalam memori, sehingga dapat dipantau secara terus-menerus selama masa pertumbuhan tanaman. Gambar 10 dan Gambar 11 menunjukkan hasil pengendalian parameter $\mathrm{pH}$ dan level larutan nutrisi pada hidroponik tanaman pakcoy.

Pada Gambar 10 tepat pukul 8:35 hingga pukul 18:20, nilai $\mathrm{pH}$ berada pada rentang nilai 6-7. Kemudian pada pukul 18:35 terukur nilai $\mathrm{pH}$ kurang dari 6, sehingga solenoid valve pada larutan basa secara otomatis terbuka untuk dialirkan pada tangki nutrisi. Proses untuk menaikkan nilai $\mathrm{pH}$ berlangsung 15 menit hingga pukul 18:50.

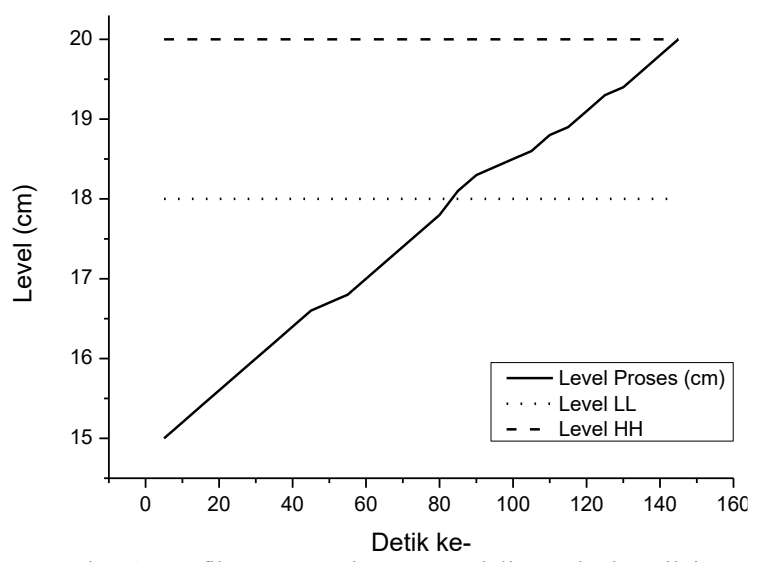

Gambar 8. Grafik respon waktu pengendalian terhadap nilai ketinggian level larutan nutrisi awal $15 \mathrm{~cm}$

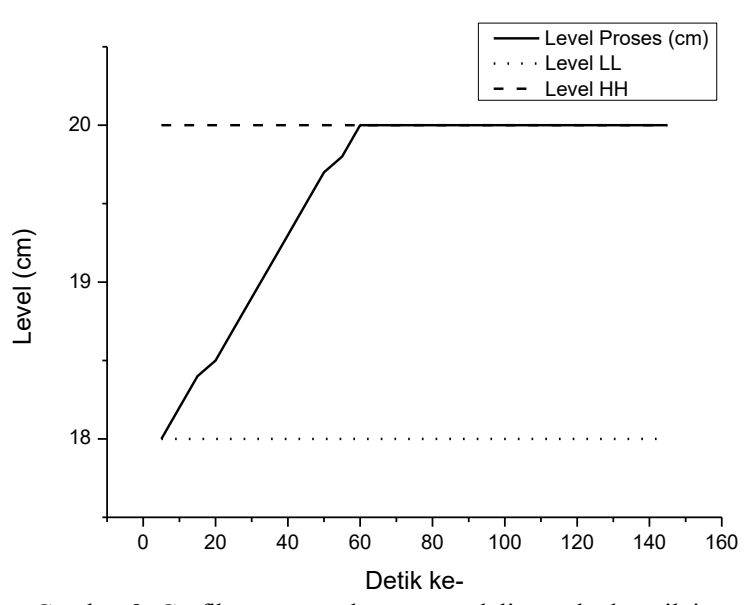

Gambar 9. Grafik respon waktu pengendalian terhadap nilai ketinggian level larutan nutrisi awal $18 \mathrm{~cm}$ 


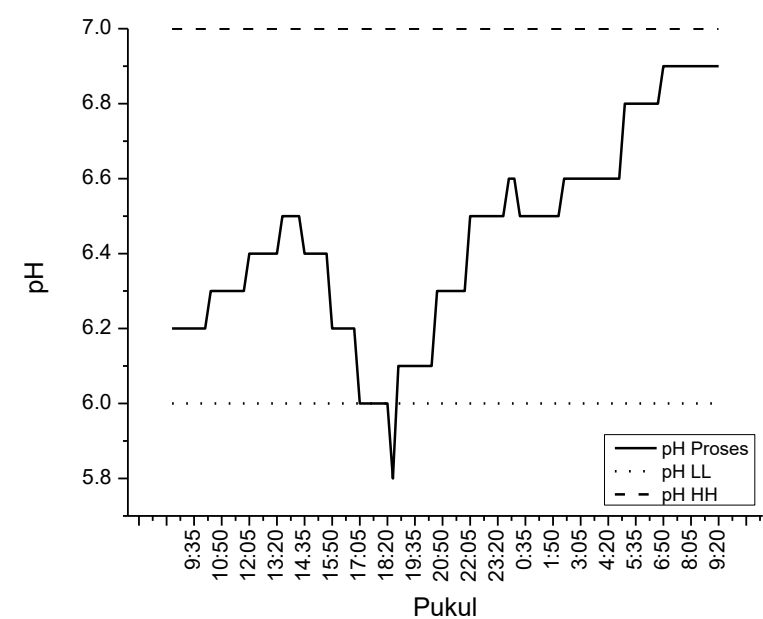

Gambar 10. Grafik pemantauan sistem pengendalian $\mathrm{pH}$ pada hidroponik tanaman pakcoy

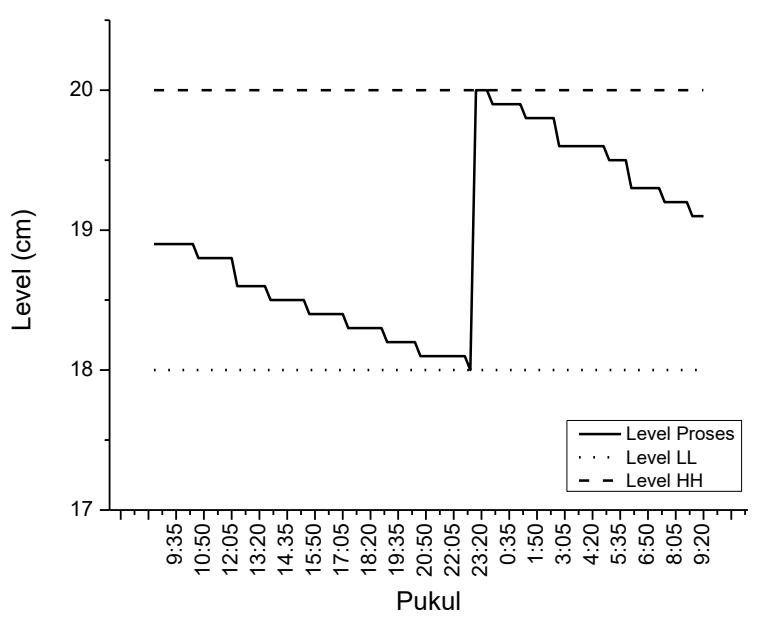

Gambar 11. Grafik pemantauan sistem pengendalian level larutan nutrisi pada hidroponik tanaman pakcoy

\begin{tabular}{|c|c|c|c|c|c|c|c|c|c|c|}
\hline \multirow{3}{*}{$\begin{array}{c}\text { Po } \\
\mathbf{t}\end{array}$} & \multicolumn{5}{|c|}{$\begin{array}{c}\text { Panjang Daun (cm) Hari } \\
\text { ke- }\end{array}$} & \multicolumn{5}{|c|}{$\begin{array}{c}\text { Jumlah Daun Hari } \\
\text { ke- }\end{array}$} \\
\hline & & & & & & & & 1 & 2 & 2 \\
\hline & 1 & 6 & 15 & 21 & 25 & 1 & 6 & 5 & 1 & 5 \\
\hline \multirow{3}{*}{1} & 1. & 2. & 6. & 11. & 12. & & 4 & 8 & 1 & 1 \\
\hline & 3 & 0 & 5 & 7 & 5 & 3 & & & 0 & 1 \\
\hline & 1. & 2. & 6. & 12. & 12. & & 5 & 7 & 1 & 1 \\
\hline \multirow[t]{2}{*}{2} & 5 & 1 & 7 & 1 & 9 & 4 & & & 0 & 1 \\
\hline & 1. & 2. & 8. & 12. & 13. & & 5 & 8 & 1 & 1 \\
\hline \multirow[t]{2}{*}{3} & 5 & 0 & 0 & 1 & 1 & 4 & & & 0 & 1 \\
\hline & 1. & 2. & 7. & 11. & 12. & & 5 & 8 & 1 & 1 \\
\hline \multirow[t]{2}{*}{4} & 3 & 0 & 9 & 9 & 8 & 4 & & & 0 & 1 \\
\hline & 1. & 1. & 7. & 11. & 12. & & 4 & 8 & 1 & 1 \\
\hline \multirow[t]{2}{*}{5} & 4 & 9 & 5 & 8 & 7 & 3 & & & 0 & 1 \\
\hline & 1. & 2. & 8. & 12. & 12. & & 5 & 8 & 1 & 1 \\
\hline \multirow[t]{2}{*}{6} & 5 & 1 & 1 & 3 & 8 & 4 & & & 0 & 1 \\
\hline & 1. & 2. & 6. & 11. & 12. & & 5 & 8 & 1 & 1 \\
\hline 7 & 5 & 1 & 5 & 2 & 5 & 4 & & & 0 & 0 \\
\hline
\end{tabular}

Gambar 11 menunjukkan hasil pengendalian level larutan nutrisi. Terlihat bahwa level larutan mengalami penurunan secara bertahap. Ketinggian level larutan nutrisi mula-mula yaitu $18,9 \mathrm{~cm}$. Kemudian pada pukul 22:50 ketinggian larutan mencapai 18,0 cm. Kondisi ini menyebabkan solenoid valve pada tangki cadangan secara otomatis terbuka untuk mengalirkan larutan nutrisi ke tangki nutrisi utama.

Penerapan smart sensor pada tanaman hidroponik terbukti mampu melakukan pengendalian terhadap operasi pertumbuhan tanaman secara terus menerus selama 24 jam setiap hari. Melalui aplikasi smart sensor ini, tanaman hidroponik pakcoy mengalami pertumbuhan yang signifikan apabila ditinjau melalui pertumbuhan jumlah dan panjang daunnya. Hasil pertumbuhan 7 buah tanaman pakcoy disajikan pada Tabel 3.

\section{KESIMPULAN}

Aplikasi smart sensor pada sistem kendali parameter $\mathrm{pH}$ dan level larutan nutrisi tanaman hidroponik pakcoy telah berhasil dirancang. Sistem kendali bekerja pada saat sensor $\mathrm{pH}$ mendeteksi nilai $\mathrm{pH}$ kurang dari 6, sehingga menyebabkan solenoid valve pada $\mathrm{pH}$ basa secara otomatis terbuka untuk menambahkan larutan nutrisi, begitu juga sebaliknya apabila sensor $\mathrm{pH}$ mendeteksi nilai $\mathrm{pH}$ lebih dari 7 . Adapun sistem kendali level bekerja ketika sensor level ultrasonik mendeteksi parameter ketinggian sebesar $18 \mathrm{~cm}$, sehingga solenoid valve akan membuka dan larutan nutrisi mengalir ke tangki nutrisi. Selanjutnya solenoid valve akan menutup kembali ketika sensor mendeteksi tinggi level larutan berada pada nilai $20 \mathrm{~cm}$. Data hasil aplikasi smart sensor pada sistem hidroponik menunjukkan bahwa jumlah dan panjang daun tanaman pakcoy meningkat secara signifikan.

\section{DAFTAR PUSTAKA}

BARBOSA, G. L., GADELHA, F. D. A., KUBLIK, N., PROCTOR, A., REICHELM, L., WEISSINGER, E., WOHLLEB, G. M. \& HALDEN, R. U. 2015. Comparison of land, water, and energy requirements of lettuce grown using hydroponic vs. conventional agricultural methods. International journal of environmental research public health, 12, 6879-6891.

BOIVIN, D., LAMY, S., LORD-DUFOUR, S., JACKSON, J., BEAULIEU, E., CÔTÉ, M., MOGHRABI, A., BARRETTE, S., GINGRAS, D. \& BÉLIVEAU, R. 2009. Antiproliferative and antioxidant activities of common vegetables: A comparative study. Food Chemistry, 112, 374-380.

BPS 2015. Badan Pusat Stastistik tentang Luas Lahan Sawah menurut Provinsi dari Tahun 20032015.

CARULlO, A. \& PARVIS, M. 2001. An ultrasonic sensor for distance measurement in automotive applications. IEEE Sensors journal, 1, 143.

FRANCISCO, M., MORENO, D. A., CARTEA, M. E., FERRERES, F., GARCÍA-VIGUERA, C. \& VELASCO, P. 2009. Simultaneous 
identification of glucosinolates and phenolic compounds in a representative collection of vegetable Brassica rapa. Journal of Chromatography, 1216, 6611-6619.

GLASOE, P. K. \& LONG, F. J. T. J. O. P. C. 1960. Use of glass electrodes to measure acidities in deuterium oxide1, 2. 64, 188-190.

HERR, I. \& BÜCHLER, M. W. 2010. Dietary constituents of broccoli and other cruciferous vegetables: implications for prevention and therapy of cancer. Cancer treatment reviews, 36, 377-383.

HUSSAIN, A., IQBAL, K., AZIEM, S., MAHATO, P. \& NEGI, A. 2014. A review on the science of growing crops without soil (Soilless Culture)-A novel alternative for growing crops. International Journal of Agriculture Crop Sciences, 7, 833.

ISTAROFAH, I. \& SALAMAH, Z. 2017. Pertumbuhan Tanaman Sawi Hijau (Brassica juncea L.) dengan Pemberian Kompos Berbahan Dasar Daun Paitan (Thitonia diversifolia). BIOSITE Biologi Sains Terapan, 3, 39-46.

KESTWAL, R. M., LIN, J. C., BAGAL-KESTWAL, D. \& CHIANG, B. H. 2011. Glucosinolates fortification of cruciferous sprouts by sulphur supplementation during cultivation to enhance anti-cancer activity. Food chemistry, 126, 1164-1171.

KIM, M. K. \& PARK, J. H. Y. 2009. Cruciferous vegetable intake and the risk of human cancer: epidemiological evidence: Conference on 'Multidisciplinary approaches to nutritional problems' Symposium on 'Nutrition and health'. Proceedings of the Nutrition Society, 68, 103-110.

NGUYEN, N. T., MCINTURF, S. A. \& MENDOZACÓZATL, D. G. 2016. Hydroponics: a versatile system to study nutrient allocation and plant responses to nutrient availability and exposure to toxic elements. Journal of visualized experiments.

NUGRAHA, R. U. 2014. Sumber Hara Sebagai Pengganti AB mix pada Budidaya Sayuran Daun Secara Hidroponik. Institut Pertanian Bogor.

RASUL, G. 2016. Managing the food, water, and energy nexus for achieving the Sustainable Development Goals in South Asia. Environmental Development, 18, 14-25.

RESH, H. M. 2016. Hydroponic food production: a definitive guidebook for the advanced home gardener and the commercial hydroponic grower, CRC Press.

ROSLIANI, R. \& SUMARNI, N. 2005. Budidaya Tanaman Sayuran dengan sistem hidroponik, Jakarta, Badan Penelitian dan Pengembangan Pertanian.
SAHA, S. K. 2010. Soilless Cultivation for Landless People: An Alternative Livelihood Practice through Indigenous Hydroponic Agriculture in Flood-prone Bangladesh. Верри: Ritsumeikan Asia Pacific University, 139152.

SARDARE, M. D. \& ADMANE, S. V. 2013. A review on plant without soil-hydroponics. International Journal of Research in Engineering Technology, 2, 299-304.

SAVVAS, D. 2003. Hydroponics: A modern technology supporting the application of integrated crop management in greenhouse. Journal of Food Agriculture Environment, $1,80-86$.

SHEIKH, B. 2006. Hydroponics: key to sustain agriculture in water stressed and urban environment. Journal of Agriculture, Agricultural Engineering and Veterinary Sciences, 22, 53-57.

VIVONDA, T. \& YOSEVA, S. 2016. Optimalisasi Pertumbuhan Dan Produksi Tanaman Pakcoy (Brassicca Rapal) Melalui Aplikasi Beberapa Dosis Pupuk Bokashi. Jurnal Online Mahasiswa Fakultas Pertanian Universitas Riau, 3, 1-11.

WAHYUNI, L. S. 2014. Uji aktivitas antibakteri ekstrak kubis (brassica oleracea l. var. capitata l.) terhadap bakteri Escherichia Coli. Universitas Islam Negeri Syarif Hidayatullah. 
Halaman ini sengaja dikosongkan 